\title{
The Narrative Memoir as a Psychoanalytical Strategy for the Research of Social Phenomena
}

\section{Andréa Máris Campos Guerra ${ }^{1 *}$, Jacqueline de Oliveira Moreira ${ }^{2 \#, ~ L o r e n a ~ V i a n n a ~ d e ~ O l i v e i r a ~}{ }^{1}$, Rodrigo Goes e Lima ${ }^{1}$}

${ }^{1}$ Department of Psychology, Federal University of Minas Gerais, Belo Horizonte, Brazil

${ }^{2}$ Department of Psychology, Pontifical Catholic University of Minas Gerais, Belo Horizonte, Brazil

Email: andreamcguerra@gmail.com, jackdrawin@yahoo.com.br, lorenavoliveira@gmail.com,rodrigo.goeselima@gmail.com

How to cite this paper: Guerra, A. M. C., de Oliveira Moreira, J., de Oliveira, L. V., \& e Lima, R. G. (2017). The Narrative Memoir as a Psychoanalytical Strategy for the Research of Social Phenomena. Psychology, $8,1238-1253$

https://doi.org/10.4236/psych.2017.88080

Received: May 25, 2017

Accepted: June 26, 2017

Published: June 29, 2017

Copyright $\odot 2017$ by authors and Scientific Research Publishing Inc. This work is licensed under the Creative Commons Attribution International License (CC BY 4.0).

http://creativecommons.org/licenses/by/4.0/

\begin{abstract}
The definition of the psychoanalytic method as an investigational method of unconscious processes allows for the interrogation of what would be the different possibilities and the listening devices available to psychoanalysis when it aims to research social phenomena. Around this question, the present article intends to explore the main methods of capturing the history of individuals, namely, the biography/autobiography, the testimony and the oral history, in order to identify the convergences and divergences of each one of these methods in relation to the psychoanalytical proposition. Based on such analysis, we endorse the narrative memoir as a genre that resembles the psychoanalytical clinical case construction, inasmuch as it considers the subjective and political dimensions that pervade the unconscious processes, without ignoring the dimension of the real displayed in the points of fiction, fixation and fantasy displayed in the researched stories.
\end{abstract}

\section{Keywords}

Psychoanalysis, Methodology, Research, Social Phenomena, Narrative Memoir

\section{Introduction}

Freud (1923/1975) defines psychoanalysis, firstly, as a "procedure for the investigation of mental processes" (p. 235), as a "method for the treatment of neurotic disorders" (p. 235), and additionally, as a "scientific discipline" (p. 235), all three of them indissociable from each other. In this article, we are particularly con-

${ }^{\star}$ A. M. C. Guerra is a grantee of FAPEMIG's "Pesquisador Mineiro" Program (PPM-Programa Pesquisador Mineiro).

"J. O. Moreira is a Level 2 CNPq's research productivity grantee (Bolsista de Produtividade em pesquisa CNPq-Nível 2). 
cerned about the first definition, concerning the investigation of mental processes. It is known that the clinical sessions, as well as the clinical case construction are important tools when it comes to collecting material for the investigation of mental processes, as well as for the intervention with patients. However, are clinical sessions the only way through which we can gather material for the investigation of mental processes? Would it be possible to create a new device to obtain access to such processes? That is the central question of the article. Could we listen to the subject outside the clinical setting, and, thus, work with the psychoanalytic method of investigation of mental processes? We could possibly inquire if psychoanalysis is interested in the classic methods of investigation of an individual, which are employed by disciplines such as Literature, History and Social Sciences. Is psychoanalysis interested in biographies/autobiographies, oral history, testimonies and narratives?

In other words, do the Freudian analysis, discussion and theorization, drawn from the information collected from his clinical cases, consider the biographical method, or do they create a new way of capturing a subject's history? It is in our interest to define and to delimit the different methods available to present an individual history, in order to introduce the psychoanalytic possibilities of researching social phenomena. We know that these four methods of data collection serve as sources of study for the fields of History, Literature and Social Sciences. We intend to uphold the idea that narrative memoirs could serve as a method for the access of subjects' histories from a psychoanalytic standpoint, allowing for the consideration of the fiction through which every history is told as a form of fixion ${ }^{1}$, apprehending the nodal points that tie the subject to the history and to his own body. In other words, we learn with the clinical method that a history is not only written in a linear way, through what is said, but also through what lies beyond it, transcending the language itself.

Towards this end, we start off by reviewing the strategies of biography/autobiography, oral history, and testimony, within the fields mentioned above, in order to examine, in the preliminary discussion, to which extent psychoanalysis differs from or relates to such methods. We then review the narratives, and introduce the field of the narrative memoir, to finally come to the propositional conclusion of the article.

Historically dated as the precursor method for approaching subjects and their histories, psychoanalysis precedes the methods described below, which originated around the 1920's. We start with the biography.

\section{Biographical Methods}

In the research field of History, according to Silva (2007), "the biographical narrative presents itself as an important historical source, considering that it depicts the character's historical context by exposing his childhood, his development, and the facts that led the individual to take his actions" (p. 11, own trans-

${ }^{1}$ Lacan's neologism in L'etourdit $(1973,2003)$, “which condenses 'fiction' and 'fixation'” (Murray, 2016). 
lation). However, although they allow for the recovery of specific elements concerning a given reality, biographies also reveal individual, fictitious and imaginary facts, which need to be distinguished as being personal and idiosyncratic.

Thus, Alberti (1991), in the field of Literature, reveals that "the fictional narrative distinguishes itself from the autobiography due to the fact that it does not refer to a reality that precedes or that is external to the text" (p. 74, own translation). On the other hand, one cannot state the opposite, that is, that every element that is part of the autobiography corresponds identitarily to an external and preceding reality. Due to the fact that an autobiography is a narrative of a subject about his own life, elements related to fantasies, to perception, to imagination and to the psychical reality are also implicated. For Alberti (1991), the autobiographies do not exhibit, necessarily, something fictional, but something related to the fixation, through which the subject builds a self-image fixed upon events, aspects and remembrances. In her own words, "and what does the autobiography author do, if not to imprint discontinuities to his life, pinpointing 'significant' episodes that fit to the text's structure, in order to elaborate (in the text, and about himself) a synthesis (something conceived)?" (Alberti, 1991: p. 77, own translation).

On this subject, the referred author takes a distance from the field of History and brings the psychoanalytic practice closer to an autobiographical reconstruction. Proceeding with her definition of autobiography, the author announces, quoting Phillipe Lejeune (1975), that "what characterizes the autobiography is the identity between the narrator and the author, expressed through the autobiographical pact established with the reader, a type of declaration such as: 'this is an autobiography'" (Alberti, 1991: p. 75, own translation). Hence, an autobiography could never be anonymous.

The investigation conducted by the sociologist Ferrarotti (1988) aiming to display the instrumentality of the biographical method distinguishes two types of materials: primary and secondary. While the primary biographical material corresponds to narratives, or to autobiographical accounts collected by a researcher, generally through interviews, the secondary biographical material represents "the biographical material of all kinds, such as: correspondences, diaries, diverse narratives, official documents, photographs, etc. whose production and existence did not have, as a goal, to serve for research purposes (p. 18, own translation)". According to the author, there is a prevalence of secondary material within the biographical method, for they are more objective. Nevertheless, the author supports the inversion of such tendency as a way to renovate the method.

Still in regards to biographies, Bueno (2002) reveals that, as a research method within the social sciences, they can be credited to the sociologists of the Chicago school, in the decades of 1920 and 1930. However, though the success of the utilization of the biographical method remained through those decades, it then "suffered a brutal and radical collapse, falling into almost complete disuse in the following decades" (Bueno, 2002: p. 16, own translation), given the severe criticisms it received. 
Some of these criticisms contributed to discrediting the method, such as the question regarding the scientific legitimacy of a production that is based on biographical data. Two aspects are revealed in this criticism: The themes of universalization, and of veracity. How is it possible to consider the history of an individual as representative of a group? In other words, how to universalize a fact out of the history of a single person? Which is the degree of credibility and of veracity of the history narrated? How does the subjectivity contained in the biographical narratives could become the object of a scientific study?

When it comes to the matter of the veracity, we recollect, along with Alberti (1991), that there is prominently, in the self-narrative, a point of fixation, and not of fiction. That is, an element that summons the subject, like a quilting point (point de capiton) of his history. Regarding the question of the potential for universalization of a single account, we learn, with Hegel (1806/1992) that the singular contains and is contained in the universal just as the universal contains and is contained in the particular and in the singular. There is a dialectic movement between the three poles, which creates the conditions both for the existence of the subject as a human category, as well as for the people, as a totality. Thus, the community, the wholeness of the people, traverses and makes itself represented in each subject, and the subject, in turn, builds his indelible impression on the community.

According to Carvalho (2003), the biographical methods used in the social sciences, in contemporary social psychology and in psychoanalysis operate in this interplay between the subject's privacy and the socio-historical space of his existence, be it widening the comprehension of the social and collective phenomena, or making emerge a subject capable of retelling the narrative about himself. We will now analyze how the question presents itself in the field of oral history.

\section{Oral History}

Regarding the oral history, we could say that it consists of a biographical method that aims to recover the memory of historical facts through individual accounts. It is characterized as a manner to tell lived experiences, and it favors the understanding of the actions and the representations of individuals or groups in a given society. Hence the denomination life history, which configures a "technique that captures what occurs in the intersection of the individual with the social" (de Queiroz, 1988: p. 36, own translation).

The first official experiences with oral history date back to 1948 with Allan Nevins, at the University of Columbia-USA. These first experiences privileged socially recognized men, such as the military, defenders of the nation. From 1960 onwards, in Great Britain, at the University of Essex, the history of ordinary people, often marginalized, such as the elderly, began to be also emphasized. This movement made possible the expansion of the method to different countries, and incentivized the research of "underground memories", as highlighted by Pollak (1989: p. 4, own translation), of silenced memories, that, had 
they not been registered, would be condemned to forgetfulness (Ferreira, 1994; de Freitas, 2002).

Haike Silva (2002) affirms, based on the works of Michael Pollak (1987), that the oral history is the result of the "affirmation struggles within the scientific field" (Silva, 2002: p. 30, own translation), constituting itself as a new field "in contrast to the dominant, official and academic history" (Silva, 2002: p. 30, own translation). Its expansion in the decades of 1960 and 1970 leads to the affirmation of the method as an instrument for social transformation, found in politically engaged researches. This perspective, however, did not present itself as hegemonic in this field, and according to Silva (2002), there has been many works being conducted concerning this field's research objects.

Hence, the oral history constitutes a biographical method that intends to capture images of the past as close to reality as possible, in a dynamic and captivating fashion, through the partnership between the interviewer and the interviewee. In general, the historical fact that one hopes to recover demands many oral testimonies, through a network of informants that is established according to the research's proposition (Giglio \& Von Simson, 2001).

Meihy (1996) affirms that the oral history is a resource utilized for the elaboration of documents, files and studies concerning people's social lives. As for the technique, the basis of the oral history is the account, the testimony, or the recorded interview. The process is established upon three foundation elements: The interviewer, the interviewee, and the recording device. The material collected in the interview is then transcribed, so that the studies can be conducted in a thorough and correct manner. It is evident that in this procedure the interviewer-interviewee interaction is highlighted as an important methodological element.

According to Matos e Senna (2011), the oral history, as a methodological process, intends to register and therefore, to perpetuate impressions, experiences and remembrances that belong to those individuals who are willing to share their memories with the collectivity, allowing, thus, for a much richer, dynamic and colorful understanding of what has been experienced, which we would not have the chance to know otherwise. It encompasses studying historical happenings, institutions, social groups, professional categories, movements and so forth. Hence, the oral history method exhibits a strong commitment to the recovery and to the factual preservation of the lived history.

Ferreira (1994) presents two directions of development of the oral history: First, one in which the testimonies have as a goal to fill the existing gaps in written documents; and a second one, that studies the representations, deriving from the relationship between memory and history.

The oral history method is also criticized, within the field of History, in regards to the credibility of the oral source. Because it is composed of subjective testimonies, it could present memory gaps and fantasy elements on the part of the individuals. According to Matos e Senna (2011), Paul Thompson (2000) responds to these criticisms arguing that no source is exempt of subjectivity and 
they are always prone to being "insufficient, ambiguous or passible of being manipulated" (Matos \& Senna, 2011: p. 102, own translation). The author defends, therefore, the use of such methodology claiming that "oral evidence can achieve something more pervasive and more fundamental to history. [...] by transforming 'objects' of study into 'subjects [...]'” (Thompson, 2000: p. 117). According to Matos \& Senna (20011), Thompson (2000) also stresses the importance of the carefulness during the transcription of the interviews, as a way to maintain the precision of the content told.

Another criticism concerning this method is that it could only be used in researches that deal with contemporary themes (Matos \& Senna, 2011). According to Matos and Senna (2011), such criticism is only sustained due to the absence or to the scarcity of specialized archives for the storage of all the material that is produced as the result of oral history researches. According to them, these files would enable the use of such materials by historians of all periods of time. As we will now see, we encounter a different proposition in the testimony.

\section{Testimony}

When it comes to the testimony, we could argue that its fiduciary dimension strengthens the relations of alterity, as the recognition of the other and the concession of a voice to the person who testifies are indispensable to the process of reconstructing the memory, understood as lived experience and marked by the selection of meanings built by the subjects involved in this process.

For Sarlo (2007),

The testimony (...) is composed of that which the subject can, or allows himself to remember, of that which he forgets, intentionally silences, modifies, invents, transfers from a genre or tone to another, of that which his cultural instruments allow himself to capture from the past, that his current ideas indicate that should be emphasized in function of a political or moral action in the present, of that which he utilizes as a rhetoric device to argue, to attack or to defend himself, of that which he knows through his own experience and through the means of communication, and that is blended after some time, with his own experience (p. 58-59, own translation).

In the struggle between remembering and forgetting, the memory presents itself as the path, par excellence, that leads the subject to acknowledging himself, historically and subjectively. Understanding memory as a process allows us to give voice to those who find themselves on the margins of the official historiography, and the testimony, in this sense, is the guarantee of the continuity of the existence, considering that, as an extension of the memory, it is what characterizes the experience of life.

The analysis of self-narratives and testimonies has gained continuously more ground in the contemporary academic production. According to Márcio Seligmann-Silva (2008), "the testimony is a modality of memory" (p. 73, own translation). Through this perspective, it could be said that "the testimony, generally, narrates the construction of collective subjectivities" (Penna, 2003: p. 311, own 
translation). Working with life testimonies means, therefore, to be open to the opportunities that such narratives make available to the understanding of the construction of these subjectivities that traverse the elaboration of the traumatic experience.

Still according to Seligmann-Silva (2005), the literature of testimony is divided into two large study areas: The studies about the Shoah, and those about the Hispanic-American "testimonio". While the Shoah conception of testimony makes itself present in Germany, France and in the United States, the "testimonio" was developed in Spanish speaking countries, above all, in Latin America. The latter represents the transition "from the reflection regarding the testimonial function of literature, as found in the Shoah, to the conceptualization of a new literary genre, that is, the 'testimonio' literature” (p. 88, own translation).

For de Marco (2004), the concept of literature of testimony is founded on problematic assumptions. The first of them is the search for the normalization of the genre. The second one is related to ideological interpretation of the production of the literature of testimony in Latin America. According to the author,

This perspective, when ignoring the interlocution with this century's interpretation of so much violence as an historical process of social exclusion, makes it harder for the reflection on the particular insertion of the last decades' Latin American literature of testimony in the moving world of literature, written by men of different languages, utopias, ethnicities, or creeds in our "era of catastrophe", when violence and barbary, as much as the capital, do not encounter geographical, political or ethnical boundaries (de Marco, 2004: p. 50, own translation).

As de Marco (2004) shows us, the testimony has consolidated itself as a research field in different study areas in response to the disasters of World War II, in an attempt to acknowledge and understand the horror of the Nazi concentration camps.

The Clinic of Testimony, in turn, is created in Brazil, through the statutes $n^{\circ}$ $12.528 / 2011$ and $\mathrm{N}^{\circ} 12.527 / 2011$, which, respectively, create the Truth Commission, and allow access to the information produced by the State over the period of the military dictatorship. It constitutes an attempt by the Brazilian State to "repair and reintegrate to our history-both the individual histories, relating to the victims, and the collective memory, of the society the psychic marks left by the serious violations of human rights" (Sigmund Freud Psychoanalytical Association, 2014: p. 15, own translation), perpetrated during the military dictatorship in the country.

The Clinic of Testimony operates through multidisciplinary teams, which summons the testimonies of those who lived the horrors of the civil-military dictatorship. According to Indursky and Piccinini (2015), the goal of such clinic is to create an environment to offer a listening service and a follow-up, considering that

Breaking the different pacts of silence, so that different voices that were 
once hidden, silenced, disappeared, can therefore emerge, is the first step of an arduous path towards the reconstruction of our history, and, therefore,

to not repeat it, as the index of a collective trauma encysted in our social fabric (p. 2, own translation).

Thus, when it comes to methodological procedures or intervention techniques, the listening of testimonies, which configures the materialization of an environment in which subjects can have a voice, could point out ways to intervene with such individuals, in an attempt to assist them in building different possibilities to their lives. Therefore, the Clinic of Testimony gains space and value, considering that it represents a space where the subject can put himself in front of a great number of representations, and of "unrepresentations" that the traumatic experience brought him. Besides, the Clinic of Testimony presents itself as a possibility of elaboration, a path to the work of remembering, that assists with the elaboration of the mourning and in the process of dealing with the untranslatable violence that inscribes itself in the body.

The Clinic of Testimony debuts an unprecedented strand in regards to the traditional methods of data collection, insofar as it constitutes an intervention with a political and reparatory background, associated with a research of historical facts, generally marked by authoritarianism, by dictatorial regimes, and other experiences related to State violence, above all. Thus, it relates to the Freudian premise that psychoanalysis is a method that attaches, indissociably, as we have seen above, theory, research, and clinical treatment.

Besides, the Clinic of Testimony is the first of the methods described above that considers the traumatic experience as determinant, an experience of the impossible in the language, as proposed by Freud. In its own intention, it attempts to attach the individual experience to the collective experience, which is not provided, in such a manner, by the Freudian clinic. Finally, because it constitutes a clinical intervention in its own nature, it is also a device with a vocation for the working-through.

\section{Preliminary Discussion}

The methods of oral history, biography/autobiography, and testimony bring important contributions to the consideration of the psychoanalytic research, though some issues related to each one of them may not be left untouched preliminarily. Even though the autobiography, as taught by Alberti (1991) presents a reconstruction of the subject through fixation points, similar to what happens in the psychoanalytical research, an autobiography is characterized by the identity between author and narrator, which entails the fact that there is no interpreter. Henceforth, for the purpose of researching social phenomena through biographies in accordance with the psychoanalytic theory, the autobiographical perspective does not suffice, from the start; given that there will always be an interpreter (other) about to read what is written as discontinuous life events. In the psychoanalytical research, the researcher appears as a symbolic mediator, after 
all, he/she interferes in the text that is being produced by inviting the subject to speak and hold the dialogue, even if just slightly, which allows us to affirm that there is the addressment of the speech, under a transferential background. ${ }^{2}$

The oral history, in turn, entails an attempt to inscribe the historical facts on the reality of collectives, groups, and communities. Therefore, it differs radically from the research of social phenomena oriented by psychoanalysis, given that for psychoanalysis, the material historicity of the facts and their historical register are considered to be less significant than the signs or the elements that fixate, symbolically, the marks that the subjects leave upon the collectives, groups and communities. Thus, through psychoanalysis, the means of registering the lived and forgotten historical facts become less important, whereas what gains prominence is the strength through which such forgotten traces resist and insist, through repetition, to reiterate themselves in the lived experiences, through the studied phenomena.

When it comes to the psychoanalytical research of social phenomena, it is of our interest to unravel the unconscious processes that come into play in the determination of the studied facts, as well as to derive, from the subject's particular position in regards to the analyzed phenomenon, elements that may collaborate to a wider interpretation of such occurrence, and that could be useful for the analysis and intervention in forthcoming situations. In this sense, not only the description of the concrete fact, but above all, the manner in which the subjectivation of the lived experience is made, interests us, hence the approximation, though in the meantime the difference, between the oral history and the "narrative memoirs".

The testimony, as "an attempt to gather the fragments of the past (that does not goes by), giving a nexus and a context to such fragments" (Seligmann-Silva, 2005: p. 87, own translation), displays similarities with the research of social phenomena oriented by psychoanalysis, given the indissociable link between research and clinical practice. On the other hand, because it is understood as a possibility of (re)constructing subjectivities and elaborating traumatic experiences under a State's reparation background, it determines symbolic positions in the power struggle, which are already pre-established. Psychoanalysis, as proposed by Freud and oriented by Lacan, entails a method that aims at enabling the extraction of a body's subjective position through language, which resonates on its political position, even though that is not the driving and central element of the elaboration. There is nothing to be repaired, but instead, something to be written as a possibility of the individual experience, which always leaves as a remainder the dimension of the indetermination and of the impossibility of representing everything. Therefore, beyond the hierarchies and the State's political dimension, which are necessarily included in the Clinic of Testimony, psychoa-

\footnotetext{
${ }^{2}$ In Psychoanalysis, the transference (Roudinesco \& Plon, 1998) refers to a "constitutive process of the psychoanalytical treatment, through which the patient's unconscious desires concerning external objects repeat themselves, within the analytical relation, in the person of the analyst, who is placed in the position of such diverse objects" (p. 766-767, own translation).
} 
nalysis inscribes itself in opposition to the regimentation of bodies, being not wholly situated in the materialist plan of the social phenomenon, given the fact that it introduces its own symbolic dimension and the jouissance, intrinsic to it, which the discourse is constantly trying to dominate.

\section{Narratives and Narrative Memoirs}

The use of narratives as a research method has presented itself as promising in the research fields of Nursery, Education, Collective Health, Psychology and Sociology/Anthropology. According to Silva and Trentini (2002), anthropology has always considered narratives "as the main form of expression used by people to tell their collective or individual saga (conquests, defeats, personal drama, joys, afflictions)" (p. 424, own translation). Galvão (2005) states that the investigation through narratives in the field of education, "more than a new paradigm, it represents the existence of an after-paradigm era, in which new configurations emerge, meanwhile the ones that already exist are still maintained" (p. 329, own translation).

Concerning the history and the development of the use of narratives as an investigative method, it is attributed to the "hermeneutic turn" (Bolívar, 2002: p. 04), embraced by the social sciences by the end of the 20th century, the reason through which it became necessary to adopt a methodology capable of considering a more humane and subjective dimension within the scientific research. According to Bolívar (2002), such epistemological orientation shift made it so that

From the positivist case it changed to an interpretative perspective, in which the meaning of the actors becomes the central focus of the investigation. The social phenomena (and, among them, education) will be understood as "texts", whose value and meaning, primarily, are given by the selfinterpretation that subjects relate in the first person, where the temporal and biographical dimension occupies a central position (p. 4).

Despite the only recent movement towards the systematization of the use of narratives as a research methodology, Bolívar (2002) traces back to authors such as Ortega y Gasset in the first half of the 20th century, a preamble of the defense and articulation of the method. According to the Spanish author, "alongside pure physio-mathematical reason there is, then, a narrative reason. To comprehend anything human, be it personal or collective, one must tell its history" (Ortega y Gasset, 1962: p. 214 as cited in Kelly Jr., 1973: p. 41).

The narratives have been taken, henceforth, as a "fundamental linguistic, psychological, cultural and philosophical framework for our attempts to come to terms with the nature and conditions of our existence" (Brockmeier \& Harré, 2001: p. 40). If the opening to new investigative paradigms is one of the reasons for the exploration of the narratives, which expands the path to the consideration of subjectivity in the scientific analysis, we are unable to recognize with clarity, however, its origin as a method. According to Mitchell \& Egudo (2003), 
"in outlining the positioning of narrative research, some articles refer to a development of narrative methodology as an extension of literary theory, or arising from narrative theory, an extension of ethnography, or even developing out of psychoanalysis" (Mitchell \& Egudo, 2003: p. 1). Regardless of its origins, it is evident, within the scientific sphere, the rising adhesion to the narrative field, which presents itself in a dual way, as Connely and Clandinin (1990) attest. As a phenomenon, "narrative names the structured quality of experience to be studied (...)", and as a method, "it names the patterns of inquiry for its study." (Connely \& Clandinin, 1990: p. 1). Reformulating his assertion, Clandinin (2016) affirms, thus, in a posterior work, that "while initially we wrote of narrative inquiry as both phenomenon and method, we quickly began to understand that it was a research methodology" (p. 11).

Brockmeier and Harré (2001) defend the narrative as a method that favors the researches in psychology and in the human sciences due to its open and flexible structure, that allows researchers to access the motions of the human experience. In Brockmeier and Harré's words "it is an essential characteristic of the narrative to be a highly sensitive guide to the variable and fleeting nature of human reality because it is, in part, constitutive of it" (Brockmeier and Harré, 2001: p. 53).

Campos and Furtado (2008), in turn, reflect upon the use of the narrative as a research method within the Collective Health field, highlighting, in their conclusion, its potentiality to "study situations in which there is interest in mediations between experience and language; between structure and events, between subjects and collective groups, or between memory and political action" (Campos and Furtado, 2008: p. 1090). The authors are inspired by Kristeva when they affirm that "it is through the narrative, and not through language in itself, that the political thought takes place" (Kristeva, 2002, p. 87, as cited in Campos and Furtado, 2008: p. 1095, own translation).

Thus, the narrative refers to the action of narrating a happening, which we could call a plot, and that presents characters that bond in time and space, in the thread sewn by the narrator. Silva and Trentini (2002) announce three important aspects concerning the construction of the narratives that need to be taken into consideration in the realm of the scientific research, namely: 1) Narratives are reconstructions, re-editions of past happenings, therefore, they comprise points of fiction and of fixation; 2) The narrator takes the listener into consideration: "the person organizes his narrative also considering who is listening to him" (p. 426); 3) "Narratives are not only the product of an individual experience, but are built dialogically, making use of popular cultural forms in order to describe shared experiences" (p. 426).

As we can see, the field of narratives as a research strategy is wide and multiform. We now turn our attention to the genre that interests us in this article, the narrative memoirs. According to Porto (2011), the expression "narrative memoir" comes from the literature, and Pedro Nava is one of the main Brazilian representative of such genre. We could also mention Luiz Alberto Mendes (2001), with his memoir novel "Memoirs of a Survivor", which offers the testi- 
mony of the life trajectory of a youngster, from childhood to adulthood, and his relation to criminality. Porto (2011) reveals that "there is a poetry in the tempo of the literary narrative; a poetical thread that turns the life narrative, through the memoir text, into one or more possibilities of existing and of resisting the forgetfulness" (Porto, 2011: p. 195, own translation).

Nevertheless, the genre is not limited to literature. Some researches in the field of History, in dialogue with the field of Education, also work with this perspective, specifically in the attempt to comprehend the influence of the life of an intellectual on the construction of a scientific field. A good example of this effort is the research led by Sbrana (2015), which aims to investigate, through the memoir discourse of Paschoal Lemme (1904-1977), his influence in the movement designated as "New School". The researcher reveals us that "for some authors, the narrative memoirs represent an important contribution to the historiographical research" (Sbrana, 2015: p. 14, own translation).

There is vast literature, amongst which we highlight Villaça (2011), Porto (2011), Aguiar et al. (2012), and Sbrana \& Cunha (2014), that attempts to delineate, predominantly through the work of Pedro Nava (but also considering Paschoal Lemme), the general characteristics of the narrative memoirs, emphasizing the "hybrid" style (Villaça, 2011: p. 69, own translation), or the "amphibious confluence" (Porto, 2011: p. 199, own translation) between history and fiction, through which the genre is developed. Specifically in regards to this genre, it is important to stress, in order to make evident its relation to the psychoanalytical method, that beyond the openness to the fictionalization, it also permits, according to the researched authors:

1) To "find in language an important tool for the memorialist" (Villaça, 2011: p. 72, own translation);

2) To consent to the fact that the memorialist may fill "his narrative with subjective elements, very personal to who takes sides on the events told" (Sbrana and Cunha, 2014: p. 326, own translation);

3) To admit that "the rescue of the past always represents a lack" (Villaça, 2011: p. 73, own translation), around which the restoration work is developed;

4) To authorize others to have an "insertion in the narrative, and not only the author-narrator" (Aguiar et al., 2012: p. 35, own translation);

5) And finally, to stimulate, drawing from the analysis of the narratives, "reflections concerning the social practices, particularly of those excluded, displaying acts of resistance or of denouncement of the prevailing hegemonic culture" (Brum, 2015: p. 44, own translation), attributing to them, thus, and a potential political dimension.

\section{Propositional Conclusion}

Finally, having gone through the different research perspectives within the human and social sciences that include the respondent in the quality of the narrator, who formulates his own history, we can conclude that the narrative memoir constitutes a rich strategic tool for the psychoanalytical research of social phe- 
nomena, in compliance with the construction of the clinical case in psychoanalysis. As proposed by Freud, we understand that the memory is prone to rearrangements, and that it contains temporal gaps, in which the narratives permanently produce history. Furthermore, it also encompasses the resignifications imprinted by the unconscious in the experience of the subject with the reality, through the language. Lastly, understanding that the truth has the structure of a fiction, it takes the real and the traumatic dimensions, which are not passible of being represented, as a research index.

[...] there is a knowledge that does not calculate, but that nonetheless works for jouissance. What can write itself of the work of the unconscious? It is there that is revealed a structure that indeed belongs to language, from its function of permitting the ciphering. Which is the meaning from which linguistics has founded an object in isolating it: named the signifier. This is the only point from which analytic discourse has to connect to science, but if the unconscious testifies to the real that is proper to it, there inversely is our chance to elucidate how language carries in the number the real from which science is elaborated (Lacan, 1973).

Thus, the use of narrative memoirs corresponds to the ethical, methodological and epistemological exigencies of psychoanalysis, inasmuch as the subject slides through the word, writing his own history, in a dimension that comprises the other, his fictions, and his fixations. Therefore, we defend the use of narrative memoirs as a strategy for the research of social phenomena oriented by psychoanalysis, given the elements presented below:

1) It includes the experience of the language, that localizes the respondent as a subject in the discourse;

2) It permits the historical facts to be narrated out of the bounds of an empirical positivist and linear rationality;

3) It understands the narrative as a fiction that paradoxically encompasses the truth;

4) It comprehends the historical marks that structure the discursive text as points of fixation, of detention, and sometimes, of impossibility of signification of one's own experience;

5) It demonstrates that the narrator's unconscious dimension makes itself present in the gaps of the discourse (the evidence of what is impossible to be said determines the location of the unconscious dimension);

6) It perceives such gaps as returning points, as points of repetition, from where new versions of a history are born;

7) It conceives the history as being written according to different versions, that relate to each other without eliminating each other in the discursive plan, considering the narrator's perspective;

8) It takes the linguistic materiality as the foundation upon which the narrative's political body is laid.

9) Thus, the narrator's perspective, when taken into consideration, exposes the background that lies behind the articulation of power, and allows for its in- 
terpretation in the composed scene.

Hence, the narrative memoirs take the narrative's status to a new level, inasmuch as it reinterprets the use of the memory and of the fiction, offering the field of memory as void of signification, and from which some sort of fixion can always be inscribed, with the operatory value of confronting the real.

\section{References}

Aguiar, J. H. C. M., Costa, D. F., Júnior, L. C. R., \& Robert, R. R. (2012). Memória e Ficção em Baú de Ossos de Pedro Nava [Memoryandfiction in Trunk of Bonesby Pedro Nava]. Revista de Ciência Política, 45, 33-53.

Alberti, V. (1991). Literatura e Autobiografia: A Questão do Sujeito na Narrativa [Literature and Autobiography: The Matter of the Subject in the Narrative]. Estudos Históricos, Rio de Janeiro, 4, 66-81.

Bolívar, A. (2002). “De Nobis Ipse Silemus?”: Epistemology of Biographical-Narrative Research in Education. Revista Electrónica de Investigación Educativa, 4, 1-24.

Brockmeier, J., \& Harré, R. (2001). Narrative: Problems and Premises of an Alternative Paradigm. In J. Brockmeier, \& D. Carbaugh (Eds.), Narrative and Identity-Studies in Autobiography, Self and Culture (pp. 39-58). Amsterdam/Philadelphia: John Benjamins Publishing Company. https://doi.org/10.1075/sin.1.04bro

Brum, A. F. (2015). O empoderamento através das narrativas memorialísticas: Ressignificando a prática Escolar [Empowerment through Memorialistic Narratives: Ressignifying The School Practice]. Master's Thesis, São Leopoldo, RS, Brasil: Faculdade EST.

Bueno, B. O. (2002). O Método Autobiográfico e os Estudos com Histórias de Vida de Professores: A Questão da Subjetividade [The Autobiographical MethodandT eachers' Life Histories Studies: The Issue of Subjectivity]. Educação e Pesquisa, São Paulo, 28, 11-30. https://doi.org/10.1590/S1517-97022002000100002

Campos, R. T. O., \& Furtado, J. P. (2008). Narrativas: Utilização na Pesquisa Qualitativa em Saúde [Narratives: Use in Qualitative Health-Related Research]. Revista de Saúde Pública, 42, 1090-1096. https://doi.org/10.1590/S0034-89102008000600016

Carvalho, I. C. M. (2003). Biografia, Identidade e Narrativa: Elementos para uma Análise Hermenêutica [Biography, Identity and Narrative: Elements for a Hermeneutical Analysis]. Horizontes Antropológicos, Porto Alegre, 9, 283-302. https://doi.org/10.1590/S0104-71832003000100012

Clandinin, D. J. (2016). Engaging in Narrative Inquiry-Developing Qualitative Inquiry (Vol. 9). New York: Routledge.

Connely, F. M., \& Clandinin, D. J. (1990). Stories of Experience and Narrative Inquiry. Educational Researcher, 19, 2-14. https://doi.org/10.3102/0013189X019005002

de Freitas, S. M. (2002). História oral: Possibilidades e procedimentos [Oral History: Possibilities and Procedures]. São Paulo: Associação Editorial Humanitas.

de Marco, V. (2004). A Literatura de Testemunho e a Violência de Estado [Literature of Testimony and State Violence]. Lua Nova: Revista de Cultura e Política, 62, 45-68. https://doi.org/10.1590/S0102-64452004000200004

de Queiroz, M. I. P. (1988). Relatosorais: Do “indizível” ao “dizível” [Oral Accounts: From the Unspeakable to the Speakable]. In O. Von Simson (Ed.), Experimentos com Histórias de Vida [Experiments with Life Histories] (pp. 14-43). São Paulo: Vértice.

Ferrarotti, F. (1988). Sobre a autonomia do método biográfico [On the Autonomy of the Biographical Method]. In A. Nóvoa, \& M. Finger (Eds.), O método (auto)biográfico e a formação [The (Auto)Biographical Method and the Formation] (pp. 17-34). Lisboa: 
Ministério da Saúde. Depart. de Recursos Humanos da Saúde/Centro de Formação e Aperfeiçoamento Profissional.

Ferreira, M. de M. (1994). História Oral: Um Inventário das Diferenças [Oral History: Aninventory of Diferences]. In Entre-vistas: Abordagens e Usos da História Oral [Interviews: Approaches and Uses of the Oral History] (pp. 1-13). Rio de Janeiro: FGV.

Freud, S. (1923/1975). Two Encyclopedia Articles (1923). In J. Strachey (Trans.), Standard Edition of the Complete Works of Sigmund Freud (Vol. 18. pp. 235-259). London: Hogarth Press.

Galvão, C. (2005). Narrativas em Educação [Narratives in Education]. Ciência \& Educação (Bauru), 11, 327-345. https://doi.org/10.1590/S1516-73132005000200013

Giglio, Z. G., \& Von Simson, O. R. M. (2001). A arte de recriar o passado: História oral e Velhicebem-sucedida [The Art of Recreating the Past: Oral History and Successful Elderliness]. In A. L. Neri (Ed.), Desenvolvimento e envelhecimento [Development and Aging] (pp. 141-160). Campinas: Papirus.

Hegel, G. W. F. (1806/1992). Fenomenologia do espírito [Phenomenology of Spirit] (1806). Trans. P. Meneses. Petrópolis: Vozes.

Indursky, A. C., \& Piccinini, C. A. (2015). O Testemunho como Ferramenta ClínicoPolítica [Testimony as a Clinical and Political Tool]. Mudanças-Psicologia da Saúde, 23, 1-9. https://doi.org/10.15603/2176-1019/mud.v23n1p1-9

Kelly Jr., F. J. (1973). The historicism of José Ortega y Gasset. Doctoral Dissertation. Norman, OK: University of Oklahoma.

Lacan, J. (1973). Introduction to a First Volume of the Écrits (Walter Verlag) (Trans. Jack W. Stone). http://www.lacanianworks.net/?p=366

Lacan, J. (2003). O aturdito [L'etourdit] (1973). In V. Ribeiro (Trans.), J. Lacan, Outros escritos [Autres Écrits] (pp. 448-497). Rio de Janeiro: Jorge Zahar.

Matos, J. S., \& Senna, A. K. (2011). História Oral como Fonte: Problemas e Métodos [Oralhistory as Source: Problems and Methods]. Historia-Rio Grande, 2, 95-108.

Meihy, J. C. S. B. (1996). Manual de história oral [Oral History Manual]. São Paulo: Edições Loyola.

Mendes, L. A. (2001). Memórias de um sobrevivente [Memoirs of a Survivor]. São Paulo: Companhia das Letras.

Mitchell, M., \& Egudo, M. (2003). A Review of Narrative Methodology (pp. 1-39). Edinburgh, Australia: Australian Government, Department of Defense, DSTO Systems Sciences Laboratory.

Murray, J. (2016). Reading Alice Munro with Jacques Lacan. Montreal, Kingston, London, Chicago: McGill-Queen's University Press.

Ortega y Gasset, J. (1962). History as a System (Trans. Helene Weyl). New York: W.W. Norton and Co., Inc.

Penna, J. C. (2003). Este corpo, estador, estafome: Notassobre o testemunhohispano-americano [This Body, This Pain, This Hunger: Notes on the Hispanic-American Testimony]. In M. Seligmann-Silva (Ed.), História, memória, literatura: O testemunho na era das catástrofes [History, Memory, Literature: The Testimony in the Era of Catastrophes] (pp. 299-354). Campinas: Ed. Unicamp.

Pollak, M. (1987) Pour un Inventaire [For an Inventory]. Les Cahiers de L'IHTP, 4 (Questions à l'histoireorale), 11-31.

Pollak, M. (1989). Memória, Esquecimento, Silêncio [Memory, Forgetting, Silence]. Revista Estudos Históricos, 2, 3-15.

Porto, P. C. P. (2011) Narrativas Memorialísticas: Memória e Literatura [Memorialistic 
Narratives: Memory and Literature]. Revista Contemporânea de Educação, 12, 195-211.

Roudinesco, E., \& Plon, M. (1998). Dicionário de psicanálise [Dictionary of Psychoanalyis]. Rio de Janeiro: Jorge Zahar.

Sarlo, B. (2007). Tempo passado: Cultura da memória e guinada subjetiva [Time Past: The Culture of Memory and the Subjective Turn]. São Paulo: Companhia das Letras; Belo Horizonte: UFMG.

Sbrana, R. A. (2015). Análise retórica da narrativa memorialística de Paschoal Lemme [Rhetoric Analysis of Narrative Memoirs of Paschoal Lemme]. Master's Thesis, São Paulo, Brasil: Universidade de São Paulo.

Sbrana, R. A., \& Cunha, M. V. (2014). A Narrativa Memorialística de Paschoal Lemme: Apontamentos para uma Análise Retórica [The Memorial Narrative of Paschoal Lemme: Notes for a Rhetorical Analysis]. Revista História e Cultura, 3, 312-328. https://doi.org/10.18223/hiscult.v3i1.1128

Seligmann-Silva, M. (2005). Testemunho e a Política da Memória: O Tempo Depois das Catástrofes [The Testimony and the Politics of Memory: The Time after Catastrophes] Projeto História, São Paulo, 30, 71-98.

Seligmann-Silva, M. (2008). Narrar o Trauma-A questão dos Testemunhos de Catástrofes Históricas [Narrating trauma-Testimonies of Historical Catastrophes]. Psicologia Clínica, Rio de Janeiro, 20, 65-82.

Sigmund Freud Psychoanalytical Association (2014). Clínicas do testemunho: reparação psíquica e construção de memórias [Clinics of Testimony: Psychical Reparation and Memory Construction]. Sigmund Freud Psychoanalytical Association (Ed.), Porto Alegre: Criação Humana.

Silva, D. G. V., \& Trentini, M. (2002). Narrativas como Técnica de Pesquisa em Enfermagem [Narrations as a Nursing Research Technique]. Revista Latino-Americana de Enfermagem, 10, 423-432. https://doi.org/10.1590/S0104-11692002000300017

Silva, H. R. K. (2002). Considerações e confusões em torno de história oral, história de vida e biografia [Considerations and Misunderstandings around Oral History, Lifehistory and Biography]. Revista MÉTIS: História \& Cultura, 1, 25-38.

Silva, M. A. de O. (2007). Biografia como Fonte Histórica [Biography as a Historical Source]. Cadernos de Pesquisa do CDHIS, 36/37, 9-15.

Statute $n^{\circ}$ 12.527, of 18 November 2011 (2011). Regulates the Access to Information as Provided for in the Subsection XXXIII of the Section 5, in the Subsection II of the Third Paragraph of the Section 37, and in the Second Paragraph of the Section 216, of the Federal Constitution; Alters the Statute $n^{\circ} 8.112$, of December, $11^{\text {th }}, 1990$; Revokes the Statute $n^{\circ} 11.111$, of May, $5^{\text {th }}, 2005$, and the Provisions of the Statute $n^{\circ} 8.159$, of January, $8^{\text {th }}, 1991$; and Sets Forth Other Provisions. Brasilia, DF. Brazil.

Statute $\mathrm{n}^{\circ}$ 12.528, of 18 November 2011 (2011). Creates the National Truth Commission within the Civil House (Executive Office) of the Presidency of the Republic. Brasilia, DF. Brazil.

Thompson, P. (2000). The Voice of the Past: Oral History (3rd ed.). Oxford: Oxford University Press.

Villaça, C. R. (2011). Pedro Nava: Os Caminhos da Memória entre o Esquecer e o Lembrar [Pedro Nava: The Memory Paths between Remembering and Forgetting]. IPOTESI-Revista de Estudos Literários, 11, 69-76. 
Submit or recommend next manuscript to SCIRP and we will provide best service for you:

Accepting pre-submission inquiries through Email, Facebook, LinkedIn, Twitter, etc. A wide selection of journals (inclusive of 9 subjects, more than 200 journals)

Providing 24-hour high-quality service

User-friendly online submission system

Fair and swift peer-review system

Efficient typesetting and proofreading procedure

Display of the result of downloads and visits, as well as the number of cited articles Maximum dissemination of your research work

Submit your manuscript at: http://papersubmission.scirp.org/

Or contact psych@scirp.org 